SAN FRANCISCO, Calif.-After rounding up more than $\$ 3$ billion of financial backing in 1991, biotechnology companies are learning that the best way to sustain enthusiasm among investors is to talk up their prospective products.

That they did at the Hambrecht \& Quist (H\&Q) tenth annual life-science investment conference here last month, which was attended by a record 1,500 potential investors. Many of the nearly 60 biotechnology companies making their cases rolled out a steady parade of product prospects that could reach the market within two or three years. Among the anticipated product approvals: bloodclotting Factor VIII for treating hemophilia from Genentech (So. San Francisco, CA), a cholesterol diagnostic test from Genzyme (Cambridge, MA), and a replacement-skin product from Advanced Tissue Sciences (La Jolla, CA).

Managers predicted a couple of dozen more genetically engineered drugs will be cleared for testing in humans, joining the more than 100 already in clinical trials. They include possible treatments for cancers, cardiac problems, and a host of autoimmune diseases, such as psoriasis, rheumatoid arthritis, and multiple sclerosis.

\section{Profits ahead}

"There is time risk-the chance that a given biopharmaceutical might not be first to market. But we believe there's been a tremendous reduction in the risk that there'll be no product at the end of the day," said David MacCallum, H\&Q's director of life sciences. "We believe that a majority of companies will be profitable within the next five to 10 years."

Among the factors playing in biotechnology's favor are last year's huge investment flow-a sum that nearly equalled all the money raised during the previous decade - and the promise of more effective and efficient products. Also, biotech drugs that show big gains in effectiveness face little immediate threat from cost-containment policies that are pushing down prices of some conventional pharmaceuticals, said Jacqueline Siegel, an H\&Q senior analyst. Still, she recommended that investors put their money on companies demonstrating an ability to hit their research benchmarks and boasting a rich product pipeline with at least some products nearing phase-I clinical trials.

Three of four biotechnology firms with approved drugs on the U.S. marketGenentech, Amgen (Thousand Oaks, CA), and Immunex (Seattle, WA)showed the richest pipelines. For its part, Genentech, with 50 potential drugs in research and development, ranks among the top 30 pharmaceutical companies worldwide, according to G. Kirk Raab, the firm's president and chief executive officer (CEO). The company has 10 potential drugs in clinical trials and expects that by 1995 three new drugs will join the three now on its product roster. Factor VIII, for one, could reach the market this year, said Raab.

\section{Chiron's rich pipeline}

Chiron (Emeryville, CA)-fresh from its merger last year with next-door-neighbor Cetus-controls some 1,700 patents and patent applications, as well as nearly a half dozen distinct businesses or joint ventures and one of the broadest product pipelines in the business. It has 12 potential drugs and four vaccines in clinical trials, along with Proleukin interleukin2 , the drug whose setback before a panel of the U.S. Food and Drug Administration (FDA, Bethesda, MD) in 1990 led to a decision by the Cetus board to start selling off business units. Edward Penhoet, Chiron's CEO, said the company is ready to make a case for Proleukin to FDA, armed with 18 months' worth of additional data that shows the durability of patient response to the drug.

Two technologies-rational drug design and genetic therapy - sparked interest. One of the fruits of rational drug design, Vertex Pharmaceuticals' (Cambridge, MA) HIV protease blocker, BX411, is on schedule to enter clinical trials late this year, according to Joshua Boger, the company's president and CEO.

Agouron Pharmaceuticals (La Jolla, CA)-which is working on several compounds to treat tumors of the brain, ovaries, and digestive system-said its AG85 entered a pilot clinical study of 10 psoriasis patients in December. The company expects another drug to enter Phase I trials in the U.K. for treating breast, pancreatic, and non-small-cell ovarian cancers.

\section{Gene-therapy strategies}

Gene-therapy companies laid out a variety of strategies for their up-andcoming products. Viagene (San Diego, CA) aims to harness retroviral vectors to deliver a genetic message to targeted cells in the body. If theory works in practice, the technique could induce stable, long-term production of cytotoxic T-lymphocytes and neutralizing antibodies to destroy infected or malignant cells.

"We believe we will be the first to file an IND (investigational new drug) application involving genetic transfer as the active component of a product," possibly within a few months, said Robert Abbott, Viagene's president and CEO.
The company's lead compound is HIV ImmunoTherapeutic, which has triggered CD8 responses that killed HIVinfected cells in mice and monkeys.

\section{MMD's biotech play}

Advances in biotechnology research continue to attract pharmaceutical majors looking for small firms with innovative products that could become the basis for joint development. Marion Merrell Dow (MMD, Kansas City, MO) is part of the trend. In the last 15 months, the company signed drug-development agreements with four development-stage biotech companies. These includeAlteon (Northvale, NJ), Affymax (Palo Alto, CA), Gensia Pharmaceuticals (San Diego, CA), and ImmuLogic Pharmaceutical (Cambridge, MA).

"Our investments in these companies are not for investment purposes," said Fred Lyons, Jr, MMD's president and CEO. "Our relationships are driven by the product relationships, the opportunities to get into new markets with innovative technologies."

The combined sales potential of products being developed with the four biotech companies could eventually rival MMD's top-selling antihistamine, Seldane, which topped $\$ 750$ million last year, Lyons said. MMD also holds equity stakes in U.S. Bioscience (West Conshohocken, PA) and in Cortech (Denver, $\mathrm{CO}$ ).

\section{Biotech's star status}

Biotechnology's regained star status among investors was reflected in the conference attendance, which shot up 20 percent from a year ago. Signalling that last year's investment boom may not have ended yet, at least four of the presenting companies cut short question sessions because of pending or recently completed stock offerings. These included Advanced Tissue Sciences, Vertex, Genta (San Diego, CA), and Gilead Sciences (Foster City, CA).

"The stock market is now willing to fund companies that are perhaps five years from profitability," said D. Larry Smith, H\&Q's director of life science research. But there were reminders that the market also quickly renders judgments on even small changes in a company's prospects. Despite recent approval for an expanded use of its drug, Leukine, Immunex's stock dropped $\$ 2.25$ a share after company officials told the conference that earnings would fall below analysts' estimates. - Ray Potter

Ray Potter-a former senior editor of BioWorld-is a freelance writer in Los Altos, CA. 